\title{
Differential impact of bortezomib on HL-60 and K562 cells
}

\author{
Katarína Klikován , Andrea Štefaniková ${ }^{1}$, Ivana Pilchová ${ }^{1}$, Jozef Hatok ${ }^{1}$, Peter Chudý2, \\ Juraj Chudej ${ }^{2}$, Dušan Dobrota ${ }^{1}$ and Peter Račay ${ }^{1}$ \\ 1 Department of Medical Biochemistry, Comenius University in Bratislava, Jessenius Faculty of Medicine in Martin, Martin, \\ Slovak Republic \\ 2 Department of Haematology and Transfusiology, University Hospital Martin, Martin, Slovak Republic
}

\begin{abstract}
Bortezomib (PS-341, or Velcade), reversible inhibitor of 20 S proteasome approved for the treatment of multiple myeloma and mantle cell lymphoma, exhibited a cytotoxic effect toward other malignancies including leukaemia. In this study, we have documented that incubation of both HL-60 and K562 leukaemia cells with nanomolar concentrations of bortezomib is associated with the death of HL-60 cells observed within 24 hours of incubation with bortezomib and the death of K562 cells that were observed after 72 hours of incubation with bortezomib. The relative resistance of K562 cells to bortezomib correlated well with significantly higher expression of HSP27, HSP70, HSP90 $\alpha$, HSP90 $\beta$ and GRP75 in these cells. Incubation of both HL-60 and K562 cells with bortezomib induced a cleavage of HSP90 $\beta$ as well as expression of HSP70 and HSP90 $\beta$ but bortezomib did not affect levels of HSP27, HSP90a, GRP75 and GRP78. The death of both types of cells was accompanied with proteolytic activation of caspase 3 that was observed in HL-60 cells and proteolytic degradation of procaspase 3 in K562 cells. Our study has also pointed to essential role of caspase 8 in bortezomib-induced cleavage of HSP90 $\beta$ in both HL-60 and K562 cells. Finally, we have shown that bortezomib induced activation of caspase 9/caspase 3 axis in HL-60 cells, while the mechanism of death of K562 cells remains unknown.
\end{abstract}

Key words: Ubiquitin proteasome system - Leukaemia - Bortezomib - Caspase - Heat shock proteins - Cell death

\section{Introduction}

Bortezomib (PS-341, or Velcade) acts as a reversible inhibitor of $20 \mathrm{~S}$ proteasome chymotrypsin-like activity that represents an execution part of ubiquitin proteasome system (Chen et al. 2011). It exhibits also certain activity against cellular serine proteases e. g. cathepsin G, cathepsin A, chymase, dipeptidyl peptidase II, and HtrA2/Omi (Arastu-Kapur et al. 2011). Bortezomib was approved for the clinical use as a front-line treatment for newly diagnosed multiple myeloma and for the treatment of relapsed/refractory multiple myeloma and mantle cell lymphoma (Chen et al. 2011). In addition to myeloma and lymphoma, bortezomib has exhibited toxic effect toward other haematological malignancies and solid

Correspondence to: Peter Račay, Department of Medical Biochemistry, Comenius University in Bratislava, Jessenius Faculty of Medicine in Martin, Mala Hora 4, 03601 Martin, Slovak Republic E-mail: racay@jfmed.uniba.sk tumours. Bortezomib can induce cell death in many cancer cell lines, showing a high efficacy in pancreatic cancer cells (Shah et al. 2001), non-small lung cancer cells (Ling et al. 2003), prostate cancer cells (Ikezoe et al. 2004), thyroid carcinoma cells (Mitsiades et al. 2006), endometrial carcinoma cells (Dolcet et al. 2006), hepatocellular carcinoma cells (Chen et al. 2008), mesothelioma cells (Zhang et al. 2010) and leukaemia cells (Matondo et al. 2010), including HL-60 and K562 cells (Colado et al. 2008; Liu et al. 2013).

In addition to induction of cell death, inhibition of ubiquitin proteasome system is associated with the induction of expression of heat shock proteins (HSPs) (Mitsiades et al. 2002) as well as with other cellular stress responses e. g. endoplasmic reticulum (ER) stress signalling (Nawrocki et al. 2005) and unfolded protein response (UPR) (Obeng et al. 2006). In turn, an increased expression of HSPs often observed in malignant cells (Romanucci et al. 2008; Ciocca et al. 2013) reduces efficacy of bortezomib that is attributed to anti-apoptotic functions of HSPs (Jego et al. 2013). 
For example, inhibition of either HSP27 (Chauhan et al. 2003) or HSP90 (Roué et al. 2011) overcomes bortezomib resistance in lymphoma cells. In human Namalwa Burkitt lymphoma cells, the resistance to bortezomib acquired by prolonged treatment of cells with bortezomib is accompanied by de novo expression of HSP27 (Fuchs et al. 2008). Recent study has also documented the potential of inhibitors of inducible HSP70 to enhance bortezomib-induced cell death in human bladder cancer cells (Qi et al. 2013). Increased expression of HSPs at the level of mRNA has also been observed in leukaemia cell lines as well as in leukaemia cells derived from peripheral blood and bone marrow of patients diagnosed with de novo acute myeloblastic leukaemia (Sedlackova et al. 2011). In addition, increased expression of HSP70 documented in leukaemia cell lines and leukaemia cells derived from peripheral blood of patients diagnosed with chronic myeloblastic leukaemia was associated with expression of Bcr-Abl fusion kinase (Guo et al. 2005).

Although significant progress has been made in defining mechanisms of bortezomib induced death of the malignant cell, mechanisms of bortezomib action are not still completely understood. The aim of the presented study was to determine the effect of bortezomib on the survival of two different leukaemic cell lines, bortezomib sensitive HL-60 cells and bortezomib resistant K562 cells characterised with expression of Bcr-Abl fusion kinase. With respect to HSPs, K562 cells exhibit significantly higher expression of HSPs genes (Sedlackova et al. 2011) and HSP70 (Guo et al. 2005) than HL60 cells. Therefore, we have also focused our interest on the analysis of the levels of HSPs in untreated HL-60 and K562 cells as well as on the analysis of the impact of bortezomib on the levels of HSPs in the cells treated with bortezomib.

\section{Materials and Methods}

Sodium dodecylsulphate (SDS), 3-(4,5-dimethylthiazol-2-yl)-2,5-diphenyltetrazolium bromide (MTT), CA-074 methyl ester (inhibitor of cathepsin B, C5857), Pepstatin A (inhibitor of cathepsin D, P5318), PD 150606 (calpain inhibitor, D5946), Q-VD-Oph (pancaspase inhibitor, SML0063) (all Sigma-Aldrich), granzyme B I inhibitor (Calbiochem, 368050), bortezomib (SC-217785), Caspase 3 Inhibitor III (SC-300325), Caspase 8 Inhibitor II (SC-3084), and Caspase 9 Inhibitor III (SC-300327) (all Santa Cruz Biotechnology). Mouse monoclonal antibodies against caspase 3 (SC-271028), HSP70 (SC-13132), HSP27 (SC13132), GRP75 (SC-133137) and $\beta$-actin (SC-47778). Goat polyclonal antibody against GRP78 (SC-1051), HSP90a (SC8262) and HSP90 $\beta$ (SC-1057). Mouse anti-goat (SC-2354) and goat anti-mouse (SC-2005) (all Santa Cruz Biotechnology) secondary antibodies conjugated with horse radish peroxidase.

\section{Cell culture}

HL-60 cells (ATCC) were maintained in IMDM medium supplemented with $20 \%$ fetal bovine serum, $1 \%$ penicillinstreptomycin (all PAA) at an optimal cell density of $0.5 \times 10^{6}$ cells $/ \mathrm{ml}$ at $37^{\circ} \mathrm{C}$ and $5 \% \mathrm{CO}_{2}$ humidified atmosphere. $\mathrm{K} 562$ cells (ATCC) were maintained in IMDM medium supplemented with $10 \%$ fetal bovine serum, $1 \%$ penicillin-streptomycin (all PAA) at an optimal cell density of $0.2 \times 10^{6}$ cells $/ \mathrm{ml}$ at $37^{\circ} \mathrm{C}$ and $5 \% \mathrm{CO}_{2}$ humidified atmosphere. The media were changed every 3 days.

\section{Cell viability and growth assay}

Cells were seeded in 96-well plates $\left(0.5 \times 10^{5} \mathrm{HL}-60\right.$ cells per well, $0.2 \times 10^{5} \mathrm{~K} 562$ cells per well) and incubated at $37^{\circ} \mathrm{C}$ and $5 \% \mathrm{CO}_{2}$ humidified atmosphere for 24, 48 and 72 hours with various concentrations of bortezomib solubilised in particular growth media. Solutions of bortezomib were prepared immediately before the use. At the end of incubation, MTT (0.05 mg per well) was added to each well and cells were further incubated for 4 hours. Formazan resulted from oxidation of added MTT by vital cells was solubilised by addition of SDS (final concentration 5\%) to each well and the optical density of formazan at $540 \mathrm{~nm}$ was determined spectrophotometrically using microplate reader Bio-Rad 2010. The relative viability of the cells was determined as ratio of optical density of formazan produced by treated cells to optical density of formazan produced by non-treated control cells and expressed as percent of control. The cell growth was determined as time course of optical density (O. D.) of formazan produced by particular cell population.

\section{Preparation of protein extracts and Western blotting}

HL-60 cells were incubated for 4, 16 and 24 hours in the presence of various concentrations of bortezomib (0-50 nmol/l). K562 cells were incubated for 24 and 48 hours in the presence of various concentrations of bortezomib (0-100 nmol/l). To study the effects of protease inhibitors, the cells were suspended at a final concentrations $0.5 \times 10^{6} \mathrm{HL}-60$ cells per $\mathrm{ml}$ and $0.2 \times 10^{6} \mathrm{~K} 562$ cells per $\mathrm{ml}$ in a growth media containing inhibitors of calpain $(100 \mu \mathrm{mol} / \mathrm{l})$, cathepsin B $(12.5 \mu \mathrm{mol} / \mathrm{l})$, granzyme B $(25 \mu \mathrm{mol} / \mathrm{l})$, caspase $3(10 \mu \mathrm{mol} / \mathrm{l})$, caspase 8 $(25 \mu \mathrm{mol} / \mathrm{l})$, caspase $9(10 \mu \mathrm{mol} / \mathrm{l})$ and pancaspase inhibitor $(20 \mu \mathrm{mol} / \mathrm{l})$ at final concentrations indicated in parentheses. After immediate addition of bortezomib, the HL-60 cells were incubated for 24 hours and K562 cells for 48 hours. At the end of incubations, the cells were harvested and washed three times with ice cold phosphate buffered saline solution. Cellular proteins were isolated from control and treated cells by extraction with TriReagent (Invitrogen) according to manufacturer's instructions. Protein concentrations were determined by protein 
Dc assay kit (Bio-Rad) using BSA as standard. Isolated proteins (30 $\mu \mathrm{g}$ of protein loaded per lane) were separated on $12 \%$ SDS-polyacrylamide gels (PAGE), transferred to nitrocellulose membrane via semidry transfer and probed with antibodies specific to HSP90a, HSP90ß, HSP70, HSP27, GRP75, GRP78, caspase 3 and $\beta$-actin. After incubation of membranes with particular secondary antibodies, immunopositive bands were visualized using the chemiluminiscent substrate SuperSignal West Pico (Thermo Scientific) and Chemidoc XRS system (Bio-Rad). Specific bands were documented and the intensities of bands were quantified by Quantity One software (Bio-Rad). The intensities of bands of interest were normalized by corresponding intensities of $\beta$-actin bands.

\section{Statistical analysis}

All statistical analyses were done using GraphPad InStat V2.04a (GraphPad Software). For the comparison of dif- ferences in protein expression between either cell types or bortezomib-induced changes among all groups at one time interval, a one-way ANOVA test was first carried out to test for differences among all experimental groups. Additionally, the unpaired Tukey's test was used to determine differences between individual groups. Significance level was set at $p<0.05$.

\section{Results}

The incubation of HL-60 and K562 cells with bortezomib for 24, 48 and 72 hours has revealed time- and concentrationdependent impact of bortezomib on relative viability of both HL-60 (Fig. 1A) and K562 cells (Fig. 1B). Bortezomib, at concentrations $10 \mathrm{nmol} / 1$ and higher, decreased relative viability of HL-60 cells already after 24 hours of incubation (Fig. 1A). The estimated lethal concentrations of bortezomib
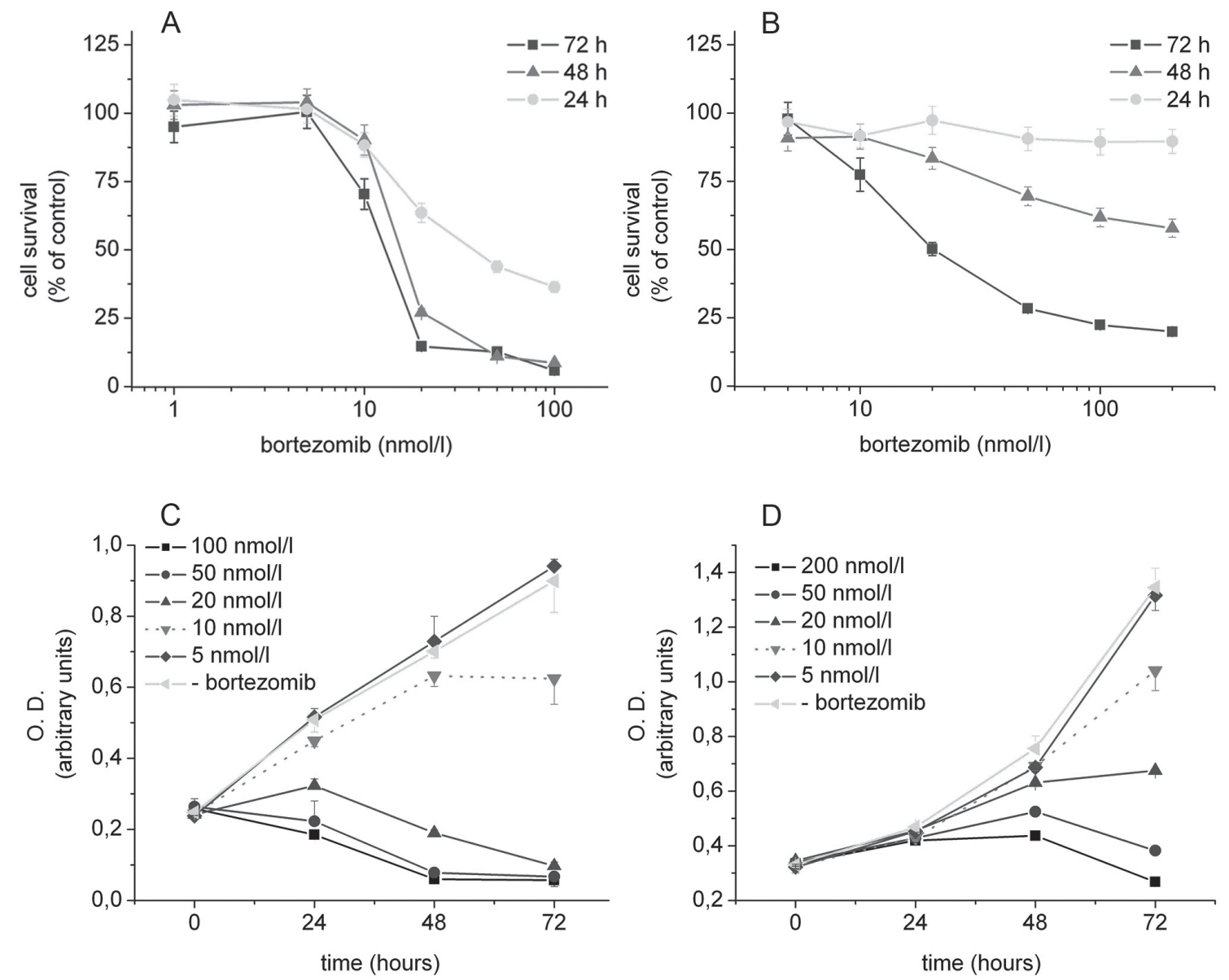

Figure 1. Effect of bortezomib on relative viability and growth of HL-60 and K562 cells. HL-60 (A, C) and K562 (B, D) cells were incubated for 24, 48 and 72 hours in the presence of various concentrations of bortezomib. Cell growth and relative cell viability were determined by the MTT assay as described in Material and Methods. Representative curve results from one experiment performed in triplicate. Data are shown as mean \pm S.D. 
leading effectively to decrease of HL-60 cell population to $50 \%$ of control $\left(\mathrm{LC}_{50}\right)$ were $39.3 \pm 4.5,16.3 \pm 0.8$ and 13.4 $\pm 0.9 \mathrm{nmol} / \mathrm{l}$ after 24,48 and 72 hours, respectively. The impact of bortezomib on the viability of K562 cells was slow and potent decrease of relative cell viability was observed after 72 hours of incubation (Fig. 1B) at concentrations of bortezomib $10 \mathrm{nmol} / \mathrm{l}$ and higher. The $\mathrm{LC}_{50}$ value for bortezomib was estimated to be $20.3 \pm 1.9 \mathrm{nmol} / \mathrm{l}$ after 72 hours.

In order to distinguish whether decreased cell viability was a result of the inhibition of cell proliferation or cell death, we have performed analysis of growth curves after the incubation of both HL-60 and K562 cells with different concentrations of bortezomib. As we have shown in our previous study (Štefaniková et al. 2013), the shape of the growth curve correlates well with a status of treated cells determined by the flow cytometry analysis. Bortezomib at a concentration $10 \mathrm{nmol} / 1$ inhibited proliferation of $\mathrm{HL}$ 60 cells that was manifested by unaltered values of optical density observed after 24, 48 and 72 hours (Fig. 1C). Bortezomib at concentrations $20 \mathrm{nmol} / \mathrm{l}$ and higher induced death of HL- 60 cells that was manifested by a continuous decrease of optical density values observed after 24, 48 and 72 hours (Fig. 1C). Bortezomib at concentrations 10 and $20 \mathrm{nmol} / \mathrm{l}$ inhibited proliferation of K562 cells that was manifested by a decreased slope of growth curves (Fig. 1D). Decreased values of optical density indicate death of K562 cells after 72 hours of incubation of cells at concentrations of bortezomib $50 \mathrm{nmol}$ and higher (Fig. 1D).

In order to explain differences in sensitivity of HL-60 and K562 cells to bortezomib we have performed Western blot analysis of the levels of HSPs that might be responsible for resistance of malignant cells to bortezomib (Jego et al. 2013) and are often over-expressed in cancer cells (Romanucci et al. 2008; Ciocca et al. 2013). In addition to cytoplasmic HSP27, HSP70 and HSP90, we have also analyzed expression of ER specific GRP78 and mitochondrial GRP75 that might be also deregulated in cancer (Lee 2014). We have found significantly higher protein level of HSP27 $(p<0.001)$, $\operatorname{HSP70}(p<0.001), \operatorname{HSP90a}(p<0.001), \operatorname{HSP} 90 \beta(p<0.001)$ and GRP75 $(p<0.05)$ in K562 cells compared with HL60 cells (Fig. 2) while difference in GRP78 protein levels between analysed cell lines was not significant. The highest differences were observed in the levels of HSP27 (30.9-fold higher expression in K562 cells) and HSP70 (14.5-fold higher expression in K562 cells).

Since proteasome stress is associated with changes of the expression of stress proteins, we have also investigated the impact of bortezomib on expression of HSP27, HSP70, HSP90, GRP75 and GRP78. We did not detect changes of the inducible HSP90a in neither K562 (Fig. 3B) nor HL-60 (not shown) treated with bortezomib. However, incubation of both HL-60 and K562 cells with bortezomib led to the cleavage of HSP90 $\beta$ that produced fragment of molecular mass of approximately $50 \mathrm{kDa}$ (Fig. 3). In both HL-60 and K562 cells, bortezomib increased expression of HSP70 but did not have significant impact on the levels of HSP27, GRP78 and GRP75 (Fig. 3). In addition to cleavage, bortezomib induced expression of HSP90 $\beta$. Although the levels of full length protein were not significantly changed, the levels of cleaved fragment of HSP90 $\beta$ increased significantly in both HL-60 (Fig. 4A,C) and K562 (Fig. 4B,D). Significantly increased levels of cleaved form of HSP90 $\beta$ were observed in HL-60 cells after 16 hours (Fig. 4A), at bortezomib concentrations 20 and $50 \mathrm{nmol} / \mathrm{l}$, and after 24 hours (Fig. 4C) at bortezomib concentrations 10, 20

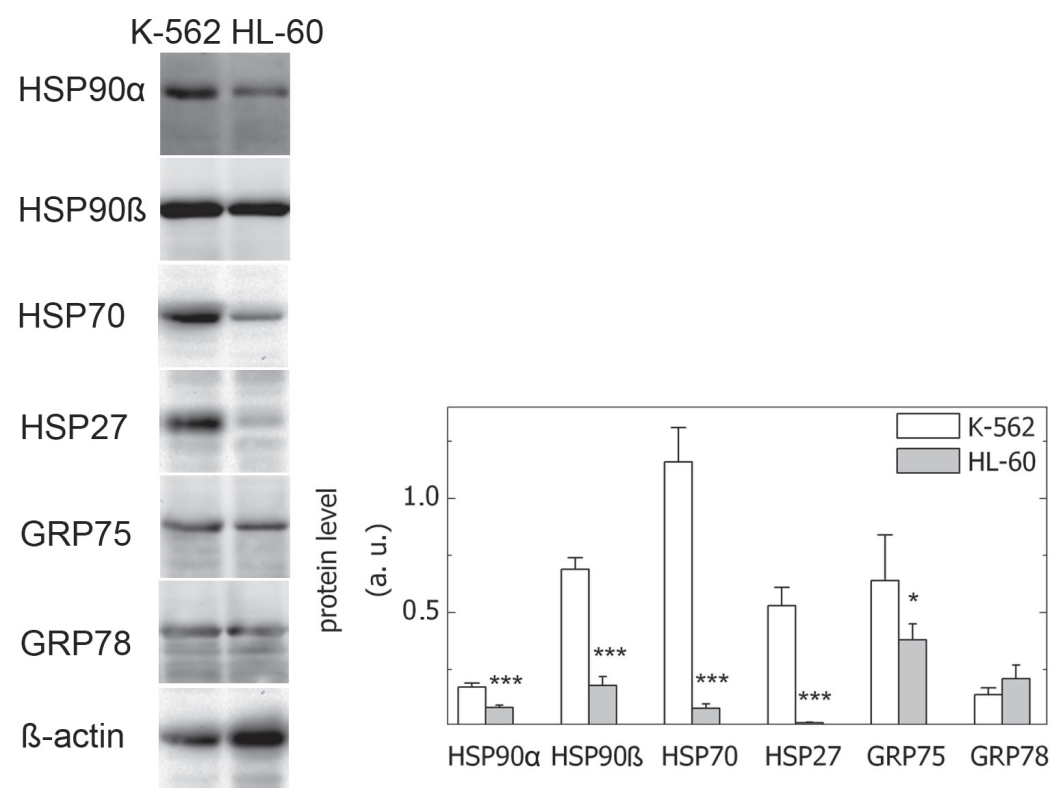

Figure 2. Analysis of HSP and GRP protein levels in HL-60 and K562. After incubation of HL-60 and K562 cells in standard growth media, cellular proteins were isolated, separated by PAGE and analysed by Western blotting as described in Material and Methods. Quantification of the HSP and GRP protein levels in HL-60 and K562 cells was performed after exposition of membranes on Chemidoc XRS (Bio-Rad). The intensities of corresponding bands were determined using Quantity One software (Bio-Rad). The data were normalised to $\beta$-actin level and expressed as intensity of band of particular protein relative to intensity of band of $\beta$-actin in particular cell type. Data are presented as means \pm S.D. ( $n=6$ per each cell line). ${ }^{*} p<0.05,{ }^{* *} p<0.001$ (ANOVA, followed by Tukey's test to determine differences between levels of particular proteins in both types of cells). 
and $50 \mathrm{nmol} / \mathrm{l}$. In K562 cells, significantly increased levels of cleaved form of HSP90 $\beta$ were observed after 48 hours at $100 \mathrm{nmol} / \mathrm{l}$ of bortezomib (Fig. 4D). Expression of HSP70 in HL-60 was significantly increased after 16 hours to $424.8 \%$ $(p<0.05)$ and $452.7 \%(p<0.05)$ of control at concentrations of bortezomib 20 and $50 \mathrm{nmol} / \mathrm{l}$, respectively (Fig. 4E). After 24 hours, the expression of HSP70 was significantly increased to $485(p<0.01), 494.1(p<0.01)$ and $474.5 \%$ $(p<0.01)$ of control at concentrations of bortezomib 10, 20 and $50 \mathrm{nmol} / \mathrm{l}$, respectively (Fig. 4E). Expression of HSP70 in K562 was significantly increased after 24 hours to $262.9 \%(p<0.01)$ of control at concentration of bortezomib $100 \mathrm{nmol} / \mathrm{l}$ and after 48 hours to $232.5(p<0.05)$ and $225.5 \%$ $(p<0.05)$ of control at concentrations of bortezomib 50 and $100 \mathrm{nmol} / \mathrm{l}$, respectively (Fig. 4F).

We have also studied the effect of bortezomib on proteolytic processing of procaspase 3. Incubation of HL-60 cells with bortezomib was associated with proteolytic activation of caspase 3 that was documented by decreased levels of procaspase 3 and increased levels of p17 fragment of active caspase 3 (Fig. 5A). On the other hand, the incubation of K652 cells with bortezomib was associated with decreased levels of procaspase 3 but we did not observe changes at the levels of p17 fragment of active caspase 3 (Fig. 5B).

In order to unveil protease that is responsible for cleavage of HSP90 $\beta$ as well as proteolytic processing of procaspase 3 we have focused our interest on cellular proteases with the known effect on either HSP90 or procaspase 3. We have incubated HL-60 and K562 cells with bortezomib in combination with inhibitors of calpain, granzyme B, cathepsin B as well as caspases 3, 8, and 9. In addition, the effect of pancaspase inhibitor on bortezomib-induced changes in HL-60 cells was investigated. As shown on Fig. 6, bortezomib-induced cleavage of HSP90 $\beta$ in both HL-60 and $\mathrm{K} 562$ cells was prevented by inhibitor of caspase 8 . Inhibitors of other proteases used in this study did not protect HSP90 $\beta$ from the bortezomib-induced cleavage. In K562 cells, granzyme B inhibitor alone was able to induce cleavage of HSP90 $\beta$ in the same way as bortezomib (Fig. 6B). In addition, inhibition of cathepsin $\mathrm{B}$ was associated with a massive and fast death of K562 cells (results not shown) that did not allow to perform a Western blot analysis. In HL-60 cells, bortezomib-induced proteolytic activation of caspase 3 (Fig. 6A) was prevented by caspase 9 inhibitor only. Interestingly, inhibitor of caspase 8 was not able to prevent bortezomib-induced proteolytic processing of procaspase 3 (Fig. 6A) that was documented by increased levels of both p 20 and p17 fragments of active caspase 3 (Fig. 6A). Finally, the incubation of HL-60 cells with cathepsin B and pancaspase inhibitor led to the bortezomib-induced proteolytic degradation of procaspase 3 as documented with the decreased levels of both procaspase 3 and p17 bands (Fig. 6A). In K562 cells, bortezomib-induced proteolytic

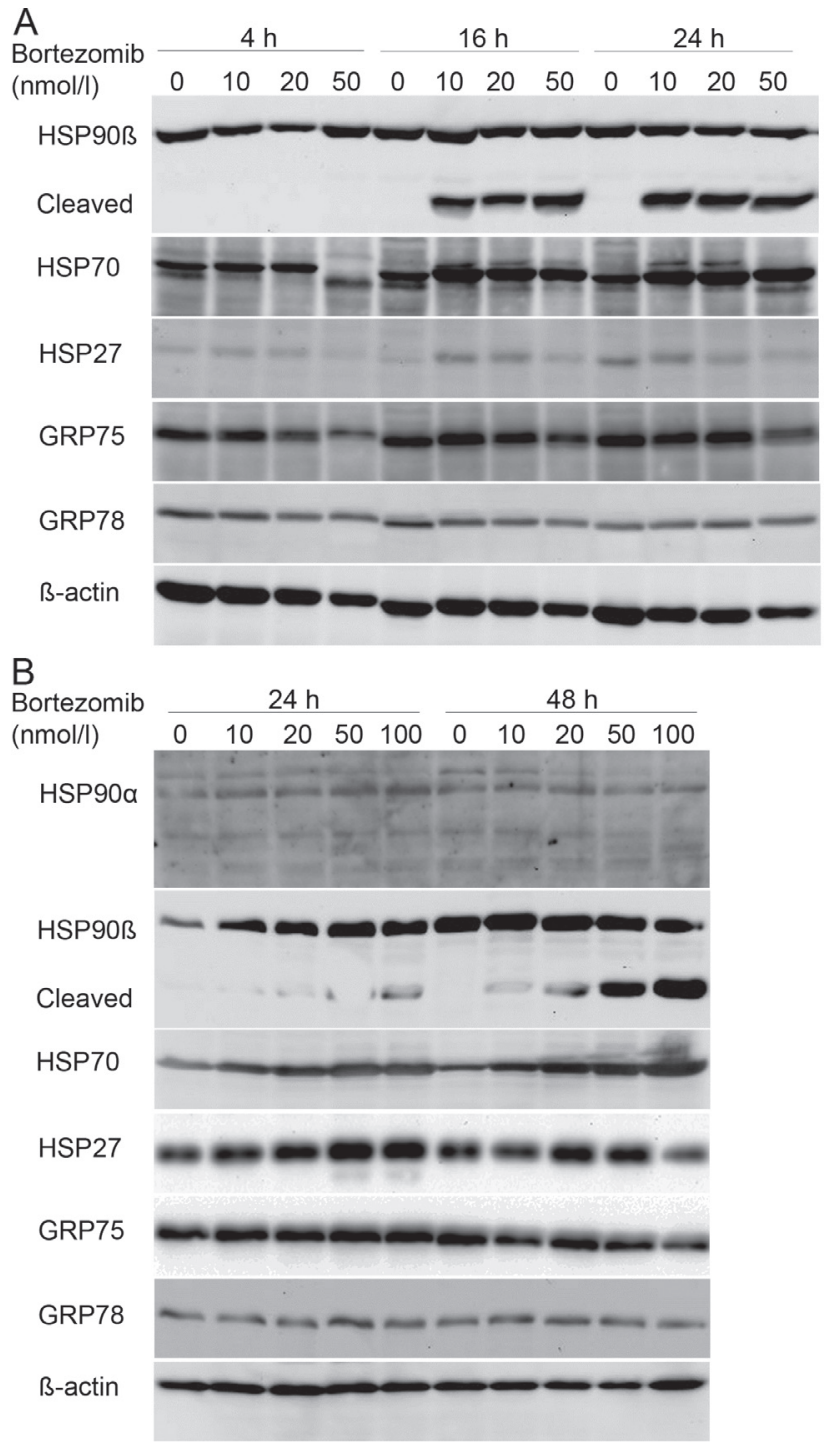

Figure 3. Effect of bortezomib on expression of HSP90 $\beta$, HSP70, HSP27, GRP75 and GRP78 in HL-60 (A) and K562 (B) cells. HL-60 cells were incubated for 4,16 and 24 hours in the presence of various concentrations of bortezomib (0-50 nmol/l). K562 cells were incubated for 24 and 48 hours in the presence of various concentrations of bortezomib (0-100 nmol/l). After incubation, cellular proteins were isolated, separated by PAGE and analysed by Western blotting as described in Material and Methods.

degradation of caspase 3 (Fig. 6B) was prevented by inhibitors of caspase 9 and calpain.

\section{Discussion}

In this study, we have documented that incubation of both HL-60 and K562 cells with bortezomib was associated with 
A

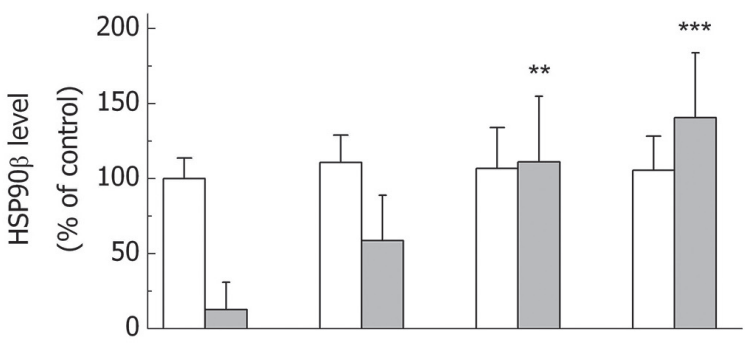

C

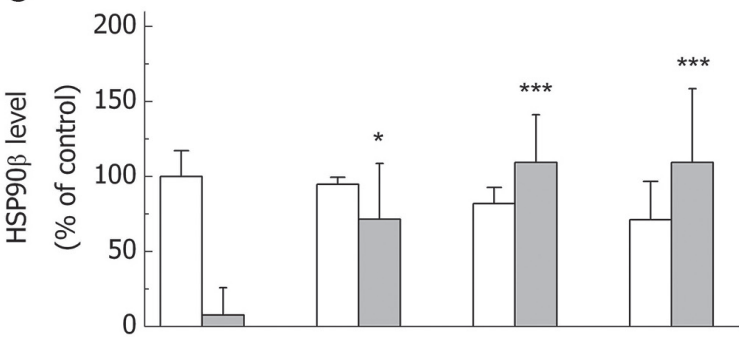

E

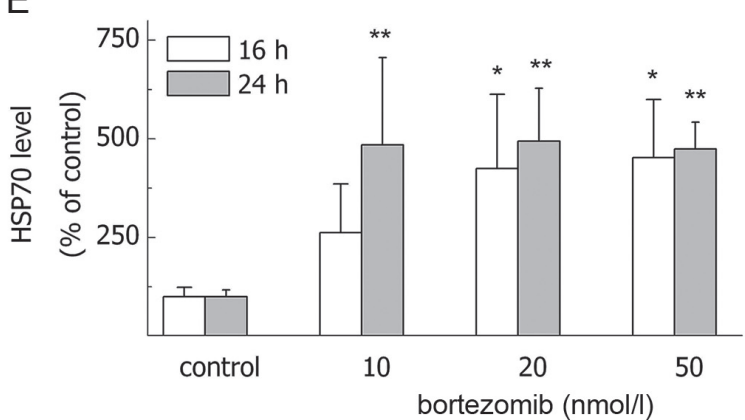

B

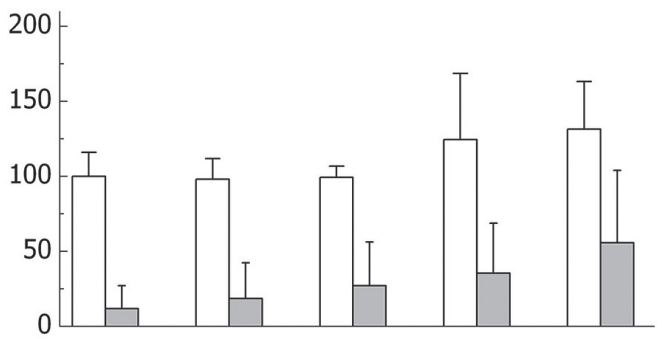

D

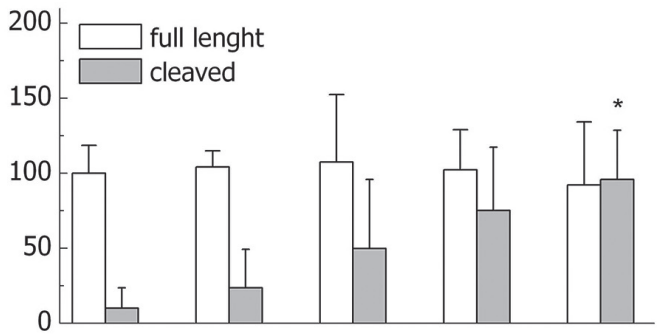

$\mathrm{F}$

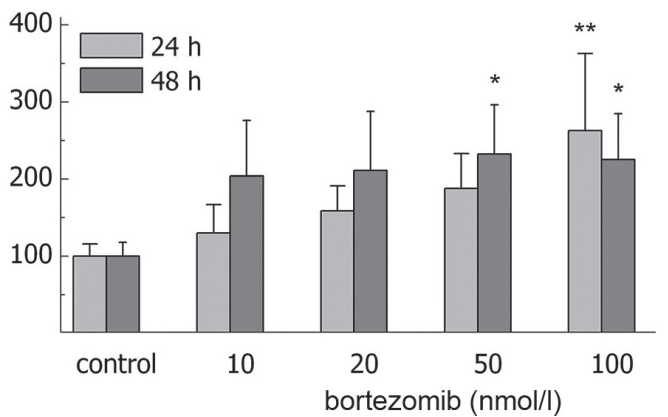

Figure 4. Quantification of the bortezomib-induced changes of HSP90 $\beta$ and HSP70 levels. Levels of HSP90 $\beta$ in HL-60 cells after 16 (A) and 24 (C) hours of incubation with borterzomib. Levels of HSP90 $\beta$ in K562 cells after 24 (B) and 48 (D) hours of incubation with borterzomib. HSP70 levels in HL-60 (E) and K562 (F) cells HL-60 cells were incubated for 16 and 24 hours in the presence of various concentrations of bortezomib (0-50 nmol/l). K562 cells were incubated for 24 and 48 hours in the presence of various concentrations of bortezomib (0-100 nmol/l). After incubation, cellular proteins were isolated, separated by PAGE and analysed by Western blotting as described in Material and Methods. The intensities of visualised bands corresponding to HSP70 were determined using Quantity One software (Bio-Rad). The data were normalised to intensity of corresponding $\beta$-actin band and expressed as relative to control (with respect to HSP90 $\beta$ full length control values were used). Data are presented as means \pm S.D. $\left(n=4\right.$ per each experimental group). ${ }^{*} p<$ $0.05,{ }^{* *} p<0.01,{ }^{* *} p<0.001$ (ANOVA, followed by Tukey's test to determine differences between levels of HSP90 $\beta$ and HSP70 in treated and control cells).

cell death, however, with different kinetics of cellular response and sensitivity of the cells to bortezomib. In addition to cell death, the bortezomib induced expression of HSP70 and HSP $90 \beta$ as well as cleavage of HSP90 $\beta$ in both HL-60 and K562 cells. We have also documented proteolytic activation of procaspase 3 in HL-60 cells and proteolytic degradation of procaspase 3 in K562 cells. Finally, our study has pointed to the essential role of caspase 8 in bortezomib-induced cleavage of HSP90 $\beta$ in both HL-60 and K562 cells.

Bortezomib induced death of HL-60 cells within 24 hours at concentrations in the low nanomolar range, within pharmacologically achievable doses. This is in agreement with previously published results documenting relative high sensitivity of HL-60 cells to bortezomib (Colado et al. 2008). Death of K562 cells was documented after 72 hours of incubation of the cells at higher bortezomib concentrations. Previous study declared K562 cells as fully resistant to bortezomib; however, the cell viability was assessed after 12 hours of incubation of cells with bortezomib (Liu et al. 2013). Differential cellular responses of investigated cells to bortezomib correlate well with higher expression of HSP27, HSP70, HSP90 and GRP75 in K562 cells. The high expression 
of HSP70 in K562 cells might be attributed to the expression of Bcr-Abl fusion kinase in K562 cells as was shown previously (Guo et al. 2005). Over-expression of HSPs (Romanucci et al. 2008; Ciocca et al. 2013) and glucose regulated proteins (GRP) (Lee 2014) often seen in cancer cells might be responsible for resistance of malignant cells to cytotoxic agents including bortezomib as well as for poor treatment response and prognosis (Jego et al. 2013). In addition to HSPs levels, sensitivity of malignant cells to bortezomib was attributed to the activity of Akt kinase (Chen et al. 2008), proteasome status (Matondo et al. 2010) and the expression of protein phosphatase 2A inhibitor (Liu et al. 2013).

The incubation of both HL-60 and K562 cells with bortezomib was associated with the increased expression of both HSP70 and HSP90 $\beta$ as well as with cleavage of HSP90 $\beta$. Induction of HSP70 represents typical molecular sequelae of proteasome inhibition (Mitsiades et al. 2002). Ectopic expression of HSP70 in HL-60 cells inhibited AraC and etoposide-induced mitochondrial apoptosis (Guo et al. 2005). We assume that bortezomib-induced expression of HSP70 in HL-60 cells did not affect the sensitivity of these cells to bortezomib. The activation of caspase 3 was observed as early as 4 hours after the addition of bortezomib whereas the increased HSP70 levels were observed after 16 hours of incubation. Thus initiation of apoptosis precedes induction of HSP70 expression. Bortezomib-dependent induc-

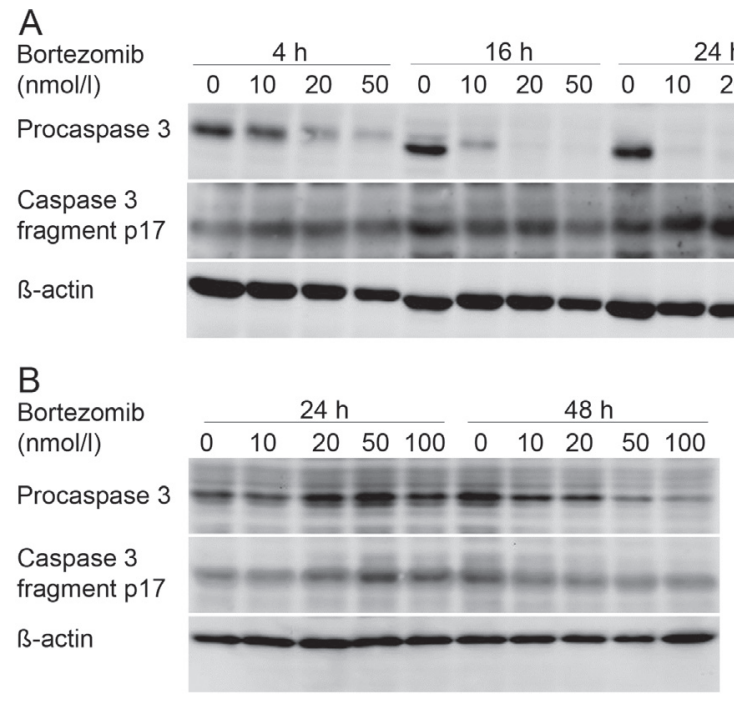

Figure 5. Effect of bortezomib on the level of procaspase 3 and active caspase 3 in HL-60 (A) and K562 (B) cells. HL-60 cells were incubated for 4,16 and 24 hours in the presence of various concentrations of bortezomib (0-50 nmol/l). K562 cells were incubated for 24 and 48 hours in the presence of various concentrations of bortezomib (0-100 nmol/l). After incubation, cellular proteins were isolated, separated by PAGE and analysed by Western blotting as described in Material and Methods.

\section{A}

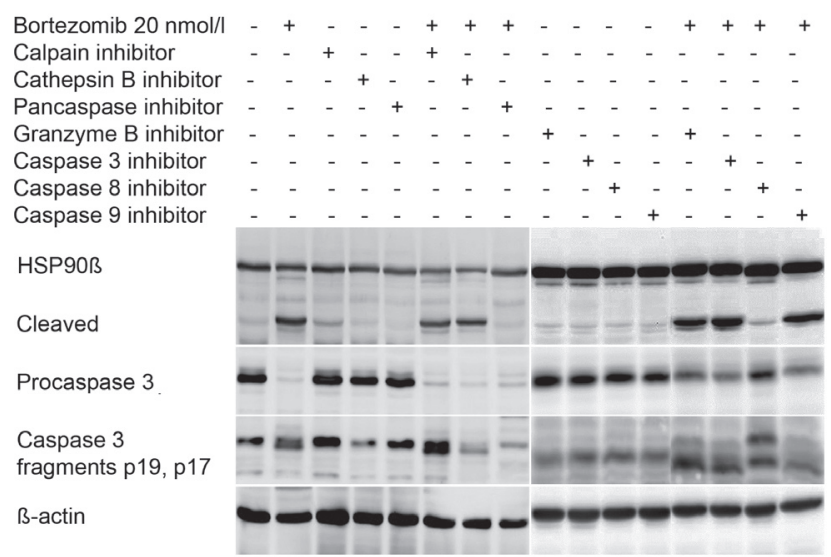

$\mathrm{B}$

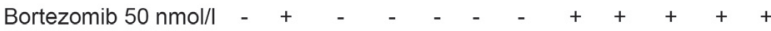

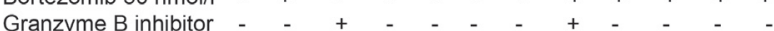

Caspase 3 ir

Caspase 8 inhibitor

Caspase 9 inhibitor

Calpain inhibitor

HSP9Oß

Cleaved

Procaspase 3

B-actin

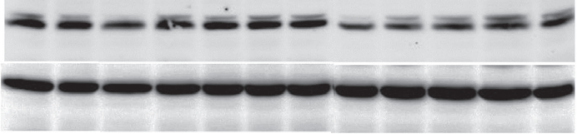

Figure 6. Effect of inhibitors of selected cellular proteases on bortezomib-induced cleavage of HSP90 $\beta$ and proteolytic processing of procaspase 3 in HL-60 (A) and K562 (B) cells. HL-60 cells were incubated with or without $20 \mathrm{nmol} / \mathrm{l}$ bortezomib for 24 hours and K562 cells were incubated with or without $50 \mathrm{nmol} / \mathrm{l}$ bortezomib for 48 hours in the absence or presence of inhibitors of calpain $(100 \mu \mathrm{M})$, cathepsin $\mathrm{B}(12.5 \mu \mathrm{M})$, granzyme $\mathrm{B}(25 \mu \mathrm{M})$, caspase 3 $(10 \mu \mathrm{M})$, caspase $8(25 \mu \mathrm{M})$, caspase $9(10 \mu \mathrm{M})$ and pancaspase inhibitor $(20 \mu \mathrm{M})$. After incubation, cellular proteins were isolated, separated by PAGE and analysed by Western blotting as described in Material and Methods.

tion of HSP90 expression has already been documented in myeloma (U266), mantle cell lymphoma (NCEB1), and breast cancer (MCF-7) cell lines (Spisek et al. 2007). To the best of our knowledge, the bortezomib-induced cleavage of HSP90 $\beta$ has not been previously reported. Caspase 10mediated cleavage of HSP $90 \beta$ producing $50 \mathrm{kDa}$ fragment has already been documented after UVB irradiation of different cells (Chen et al. 2009). Caspase 10 activation was depended on caspase 8 , which cleaved procaspase 10 directly (Chen et al. 2009). In addition, calpain-specific cleavage of HSP90 producing $50 \mathrm{kDa}$ fragment that was prevented by somatostatin was observed in macrophages (Bellocq et al. 1999). Our results are not in favour of the involvement of calpain in the process of bortezomib-in- 
duced cleavage of HSP90 $\beta$ in both HL-60 and K562 cells. Instead of this, we have shown that the bortezomib induced cleavage of HSP90 $\beta$ through the action of caspase 8 . This is in agreement with previous studies that have documented activation of caspase 8 after the incubation of different cancer cells with proteasome inhibitors (Colado et al. 2008; Laussmann et al. 2011; Fiandalo et al. 2013) including HL60 cells (Choi et al. 2008). Since it has been documented that HSP90 $\beta$ is a substrate of caspase 10 but not caspase 8 (Chen et al. 2009), we assume that caspase 8 is the initiator of this process while caspase 10 is responsible for direct cleavage of HSP90 $\beta$. On the other hand, previous studies (Beck et al. 2009, 2012) have documented the cleavage of HSP90 mediated by oxidative stress that is often implicated among mechanisms of cytotoxic action of bortezomib (Yu et al. 2004). This cleavage produced fragment of $72 \mathrm{kDa}$ and was associated with the degradation of HSP90 client proteins that was considered as the main event leading to cell death. Production of $50 \mathrm{kDa}$ fragments and prevention of the HSP90 $\beta$ cleavage by the inhibitor of caspase 8 and pancaspase inhibitor exclude the possibility that bortezomib-induced degradation of HSP90 $\beta$ is mediated by oxidative stress.

In agreement with previously published results (Choi et al. 2008), we have also shown that the bortezomib induced proteolytic activation of procaspase 3 in HL-60 cells manifested by the increase of $\mathrm{p} 17$ fragment of active caspase 3. In K562 cells, the bortezomib-induced decrease of procaspase 3 was not associated with the production of p17 fragment of caspase 3. Caspase 3 represents the main execution caspase of apoptosis. Its proteolytic activation via either caspase 8 , in the case of extrinsic (receptor) apoptosis pathway, or caspase 9 , in the case of intrinsic (mitochondrial) pathway (Jurečeková et al. 2011), leads to the degradation of a number of essential cellular proteins that culminates in the cell death (Taylor et al. 2008). Our results have documented that incubation of HL-60 cells with bortezomib is associated with the activation of caspase 3 mediated by caspase 9 since the inhibition of caspase 9 prevented bortezomib-induced activation of caspase 3 . These results are in agreement with the earlier suggestion that mitochondrial apoptosis is the main pathway associated with bortezomib-induced cell death (Chauhan et al. 2004; Fennell et al. 2008). We have also observed that despite the inhibitory effect of caspase 8 inhibitor on the bortezomib-induced cleavage of HSP90 $\beta$ the same inhibitor did not exhibit inhibitory effect on caspase 3 activation. It seems that activation of caspase 3 via caspase 9 precedes the cleavage of HSP90 $\beta$ via caspase 8. In fact, changes at the level of active caspase 3 were observed already after 4 hours of incubation of HL-60 cells with bortezomib (Fig. $5 \mathrm{~A})$ while cleavage of HSP $90 \beta$ was detected after 16 hours (Fig. 3A). Interestingly, pancaspase inhibitor Q-VD-Oph used in this study (that simultaneously inhibits caspases 1 , $3,8,9)$ did not prevent the bortezomib-induced proteolytic processing of procaspase 3 . This result might indicate that proteolytic processing of procaspase 3 is not only dependent on caspase 9 but is also associated with another cellular protease that became to be active after simultaneous inhibition of caspases 8 and 9. In addition to caspase 9, caspase 3 can be activated by granzyme B (Zapata et al. 1998). However, the inhibitor of granzyme $B$ did not prevent the bortezomibinduced activation of caspase 3 . We can also exclude the activation of caspase 3 by the action of calpain. However, our results indicate unclear involvement of cathepsin B that might be released from lysosomes after the incubation of cells with bortezomib (Yeung et al. 2006) in proteolytic processing of procaspase 3. In HL-60 cells, the inhibition of cathepsin B promoted bortezomib-induced disappearance of procaspase 3 signal without increase of p17 signal of active caspase 3. Interestingly, cathepsin B inhibitor induced fast and massive death of K562 cells.

There is an important question whether degradation of HSP90 $\beta$ might be involved among mechanisms of the bortezomib-induced cell death. HSP90 is a chaperone necessary for the folding, stability and activity of numerous cellular proteins that are essential for the growth and survival of eukaryotic cells (Barrott and Haystead 2013). Blocking or deletion of HSP90 is associated with death of different cancer cells (Barrott and Haystead 2013). Our results do not support a role of proteolytic processing of HSP90 $\beta$ in the bortezomib-induced death of HL-60 and K562 cells. The pancaspase inhibitor prevented the bortezomib-induced cleavage of HSP90 $\beta$ but did not protect HL-60 cells from bortezomib-induced cell death. The inability of the pancaspase inhibitor to protect HL-60 from bortezomib-induced cell death does not exclude mitochondrial apoptosis as mechanism of the bortezomib-induced death of HL-60 cells. It has been shown previously that bortezomib was capable of killing lymphoma cells through activation of either mitochondrial apoptosis or caspase-independent mechanisms when caspases were pharmacologically inhibited (Olejniczak et al. 2010).

In conclusion, our experiments have documented that the incubation of HL-60 and K562 cells with bortezomib led to cell death that is associated with the cleavage of HSP90 $\beta$ as well as with proteolytic activation of caspase 3 in HL-60 cells and the proteolytic degradation of procaspase 3 in K562 cells. The difference in cell death kinetics might be attributed to significantly higher expression of HSP90, HSP70, HSP27 and GRP75 documented in K562. Our study has also pointed to the essential role of caspase 8 in the bortezomibinduced cleavage of HSP $90 \beta$ in both HL-60 and K562 cells. Finally, we have shown that bortezomib induced activation of caspase 9/caspase 3 axis in HL-60 cells, while mechanism of death of K562 cells remains unknown. 
Acknowledgments. This work was supported by project „Support of human resources development using the most modern methods and forms of education on JFM CU in Martin" co-financed from European Union sources and European Social Fund to A. S. and by APVV grant No. 0245-11 to P. R.

\section{References}

Arastu-Kapur S., Anderl J. L., Kraus M., Parlati F., Shenk K. D. Lee S. J., Muchamuel T., Bennett M. K., Driessen C., Ball A. J., Kirk C. J. (2011): Nonproteasome targets of the proteasome inhibitors bortezomib and carfilzomib: a link to clinical adverse events. Clin. Cancer Res. 17, 2734-2743 http://dx.doi.org/10.1158/1078-0432.CCR-10-1950

Barrott J. J., Haystead T. A. (2013): Hsp90, an unlikely ally in the war on cancer. FEBS J. 280, 1381-1396 http://dx.doi.org/10.1111/febs.12147

Beck R., Verrax J., Gonze T., Zappone M., Pedrosa R. C., Taper H., Feron O., Calderon P. B. (2009): Hsp90 cleavage by an oxidative stress leads to its client proteins degradation and cancer cell death. Biochem. Pharmacol. 77, 375-383 http://dx.doi.org/10.1016/j.bcp.2008.10.019

Beck R., Dejeans N., Glorieux C., Creton M., Delaive E., Dieu M., Raes M., Levêque P., Gallez B., Depuydt M., Collet J. F., Calderon P. B., Verrax J. (2012): Hsp90 is cleaved by reactive oxygen species at a highly conserved $\mathrm{N}$-terminal amino acid motif. PLoS One 7, e40795 http://dx.doi.org/10.1371/journal.pone.0040795

Bellocq A., Doublier S., Suberville S., Perez J., Escoubet B., Fouqueray B., Puyol D. R., Baud L. (1999): Somatostatin increases glucocorticoid binding and signaling in macrophages by blocking the calpain-specific cleavage of Hsp 90. J. Biol. Chem. 274, 36891-3689 http://dx.doi.org/10.1074/jbc.274.52.36891

Chauhan D., Li G., Shringarpure R., Podar K., Ohtake Y., Hideshima T., Anderson K. C. (2003): Blockade of Hsp27 overcomes Bortezomib/proteasome inhibitor PS-341 resistance in lymphoma cells. Cancer Res. 63, 6174-6177

Chauhan D., Li G., Podar K., Hideshima T., Mitsiades C., Schlossman R., Munshi N., Richardson P., Cotter F. E., Anderson K. C. (2004): Targeting mitochondria to overcome conventional and bortezomib/proteasome inhibitor PS-341 resistance in multiple myeloma (MM) cells. Blood 104, 2458-2466 http://dx.doi.org/10.1182/blood-2004-02-0547

Chen K. F., Yeh P. Y., Yeh K. H., Lu Y. S., Huang S. Y., Cheng A. L. (2008): Down-regulation of phospho-Akt is a major molecular determinant of bortezomib-induced apoptosis in hepatocellular carcinoma cells. Cancer Res. 68, 6698-6707 http://dx.doi.org/10.1158/0008-5472.CAN-08-0257

Chen H., Xia Y., Fang D., Hawke D., Lu Z. (2009): Caspase-10-mediated heat shock protein 90 beta cleavage promotes UVB irradiation-induced cell apoptosis. Mol. Cell. Biol. 29, 3657-3664 http://dx.doi.org/10.1128/MCB.01640-08

Chen D., Frezza M., Schmitt S., Kanwar J., Dou Q. P. (2011): Bortezomib as the first proteasome inhibitor anticancer drug: current status and future perspectives. Curr. Cancer Drug Targets 11, 239-253 http://dx.doi.org/10.2174/156800911794519752

Choi M. R., Najafi F., Safa A. R., Drexler H. C. (2008): Analysis of changes in the proteome of HL-60 promyeloid leukemia cells induced by the proteasome inhibitor PSI. Biochem. Pharmacol. 75, 2276-2288 http://dx.doi.org/10.1016/j.bcp.2008.03.017

Ciocca D. R., Arrigo A. P., Calderwood S. K. (2013): Heat shock proteins and heat shock factor 1 in carcinogenesis and tumor development: an update. Arch. Toxicol. 87, 19-48 http://dx.doi.org/10.1007/s00204-012-0918-z

Colado E., Alvarez-Fernández S., Maiso P., Martín-Sánchez J., Vidriales M. B., Garayoa M., Ocio E. M., Montero J. C., Pandiella A., San Miguel J. F. (2008): The effect of the proteasome inhibitor bortezomib on acute myeloid leukemia cells and drug resistance associated with the $\mathrm{CD} 34+$ immature phenotype. Haematologica 93, 57-66 http://dx.doi.org/10.3324/haematol.11666

Dolcet X., Llobet D., Encinas M., Pallares J., Cabero A., Schoenenberger J. A., Comella J. X., Matias-Guiu X. (2006): Proteasome inhibitors induce death but activate NF-kappaB on endometrial carcinoma cell lines and primary culture explants. J. Biol. Chem. 281, 22118-22130 http://dx.doi.org/10.1074/jbc.M601350200

Fennell D. A., Chacko A., Mutti L. (2008): BCL-2 family regulation by the $20 \mathrm{~S}$ proteasome inhibitor bortezomib. Oncogene 27, 1189-1197 http://dx.doi.org/10.1038/sj.onc.1210744

Fiandalo M. V., Schwarze S. R., Kyprianou N. (2013): Proteasome regulation of caspase-8 in cancer cell apoptosis. Apoptosis 18, 766-776 http://dx.doi.org/10.1007/s10495-013-0821-y

Fuchs D., Berges C., Opelz G., Daniel V., Naujokat C. (2008): Increased expression and altered subunit composition of proteasomes induced by continuous proteasome inhibition establish apoptosis resistance and hyperproliferation of Burkitt lymphoma cells. J. Cell Biochem. 103, 270-283 http://dx.doi.org/10.1002/jcb.21405

Guo F., Sigua C., Bali P., George P., Fiskus W., Scuto A., Annavarapu S., Mouttaki A., Sondarva G., Wei S., Wu J., Djeu J., Bhalla K. (2005): Mechanistic role of heat shock protein 70 in Bcr-Ablmediated resistance to apoptosis in human acute leukemia cells. Blood 105, 1246-1255 http://dx.doi.org/10.1182/blood-2004-05-2041

Ikezoe T., Yang Y., Saito T., Koeffler H. P., Taguchi H. (2004): Proteasome inhibitor PS-341 down-regulates prostate-specific antigen (PSA) and induces growth arrest and apoptosis of androgen-dependent human prostate cancer LNCaP cells. Cancer Sci. 95, 271-275 http://dx.doi.org/10.1111/j.1349-7006.2004.tb02215.x

Jego G., Hazoumé A., Seigneuric R., Garrido C. (2013): Targeting heat shock proteins in cancer. Cancer Lett. 332, 275-285 http://dx.doi.org/10.1016/j.canlet.2010.10.014

Jurečeková J., Hatok J., Stefániková A., Dobrota D., Račay P. (2011): Targeting of Bcl-2 family proteins for treatment of acute leukaemia. Gen. Physiol. Biophys. 30, S3-12 http://dx.doi.org/10.4149/gpb_2011_SI1_3

Laussmann M. A., Passante E., Düssmann H., Rauen J. A., Würstle M. L., Delgado M. E., Devocelle M., Prehn J. H., Rehm M. 
(2011): Proteasome inhibition can induce an autophagy-dependent apical activation of caspase-8. Cell Death Differ. 18, 1584-1597

http://dx.doi.org/10.1038/cdd.2011.27

Lee A. S. (2014): Glucose-regulated proteins in cancer: molecular mechanisms and therapeutic potential. Nat. Rev. Cancer 14, 263-276

http://dx.doi.org/10.1038/nrc3701

Ling Y. H., Liebes L., Jiang J. D., Holland J. F., Elliott P. J., Adams J., Muggia F. M., Perez-Soler R. (2003): Mechanisms of proteasome inhibitor PS-341-induced G(2)-M-phase arrest and apoptosis in human non-small cell lung cancer cell lines. Clin. Cancer Res. 9, 1145-1154

Liu C. Y., Shiau C. W., Kuo H. Y., Huang H. P., Chen M. H., Tzeng C. H., Chen K. F. (2013): Cancerous inhibitor of protein phosphatase $2 \mathrm{~A}$ determines bortezomib-induced apoptosis in leukemia cells. Haematologica 98, 729-738 http://dx.doi.org/10.3324/haematol.2011.050187

Matondo M., Bousquet-Dubouch M. P., Gallay N., UttenweilerJoseph S., Recher C., Payrastre B., Manenti S., Monsarrat B., Burlet-Schiltz O. (2010): Proteasome inhibitor-induced apoptosis in acute myeloid leukemia: a correlation with the proteasome status. Leuk. Res. 34, 498-506 http://dx.doi.org/10.1016/j.leukres.2009.09.020

Mitsiades N., Mitsiades C. S., Poulaki V., Chauhan D., Fanourakis G., Gu X., Bailey C., Joseph M., Libermann T. A., Treon S. P., Munshi N. C., Richardson P. G., Hideshima T., Anderson K. C. (2002): Molecular sequelae of proteasome inhibition in human multiple myeloma cells. Proc. Natl. Acad. Sci. USA 99, 14374-14379 http://dx.doi.org/10.1073/pnas.202445099

Mitsiades C. S., McMillin D., Kotoula V., Poulaki V., McMullan C., Negri J., Fanourakis G., Tseleni-Balafouta S., Ain K. B., Mitsiades N. (2006): Antitumor effects of the proteasome inhibitor bortezomib in medullary and anaplastic thyroid carcinoma cells in vitro. J. Clin. Endocrinol. Metab. 91, 4013-4021 http://dx.doi.org/10.1210/jc.2005-2472

Nawrocki S. T., Carew J. S., Dunner K. Jr., Boise L. H., Chiao P. J., Huang P., Abbruzzese J. L., McConkey D. J. (2005): Bortezomib inhibits PKR-like endoplasmic reticulum (ER) kinase and induces apoptosis via ER stress in human pancreatic cancer cells. Cancer Res. 65, 11510-11519 http://dx.doi.org/10.1158/0008-5472.CAN-05-2394

Obeng E. A., Carlson L. M., Gutman D. M., Harrington W. J. Jr., Lee K. P., Boise L. H. (2006): Proteasome inhibitors induce a terminal unfolded protein response in multiple myeloma cells. Blood 107, 4907-4916

http://dx.doi.org/10.1182/blood-2005-08-3531

Olejniczak S. H., Blickwedehl J., Belicha-Villanueva A., Bangia N., Riaz W., Mavis C., Clements J. L., Gibbs J., Hernandez-Ilizaliturri F. J., Czuczman M. S. (2010): Distinct molecular mechanisms responsible for bortezomib-induced death of therapy-resistant versus-sensitive B-NHL cells. Blood 116, 5605-5614 http://dx.doi.org/10.1182/blood-2009-12-259754

Qi W., White M. C., Choi W., Guo C., Dinney C., McConkey D. J., Siefker-Radtke A. (2013): Inhibition of inducible heat shock protein-70 (hsp72) enhances bortezomib-induced cell death in human bladder cancer cells. PLoS One 8, e69509 http://dx.doi.org/10.1371/journal.pone.0069509
Romanucci M., Bastow T., Della Salda L. (2008): Heat shock proteins in animal neoplasms and human tumours--a comparison. Cell. Stress Chaperones 13, 253-262 http://dx.doi.org/10.1007/s12192-008-0030-8

Roué G., Pérez-Galán P., Mozos A., López-Guerra M., Xargay-Torrent S., Rosich L., Saborit-Villarroya I., Normant E., Campo E., Colomer D. (2011): The Hsp90 inhibitor IPI-504 overcomes bortezomib resistance in mantle cell lymphoma in vitro and in vivo by down-regulation of the prosurvival ER chaperone BiP/Grp78. Blood 117, 1270-1279 http://dx.doi.org/10.1182/blood-2010-04-278853

Sedlackova L., Spacek M., Holler E., Imryskova Z., Hromadnikova I. (2011): Heat-shock protein expression in leukemia. Tumour Biol. 32, 33-44 http://dx.doi.org/10.1007/s13277-010-0088-7

Shah S. A., Potter M. W., McDade T. P., Ricciardi R., Perugini R. A., Elliott P. J., Adams J., Callery M. P. (2001): 26S proteasome inhibition induces apoptosis and limits growth of human pancreatic cancer. J. Cell. Biochem. 82, 110-122 http://dx.doi.org/10.1002/jcb.1150

Spisek R., Charalambous A., Mazumder A., Vesole D. H., Jagannath S., Dhodapkar M. V. (2007): Bortezomib enhances dendritic cell (DC)-mediated induction of immunity to human myeloma via exposure of cell surface heat shock protein 90 on dying tumor cells: therapeutic implications. Blood 109, 4839-4845 http://dx.doi.org/10.1182/blood-2006-10-054221

Štefaniková A., Kliková K., Hatok J., Račay P. (2013): ABT-737 accelerates butyrate-induced death of HL-60 cells. Involvement of mitochondrial apoptosis pathway. Gen. Physiol. Biophys. 32, 505-516 http://dx.doi.org/10.4149/gpb_2013053

Taylor R. C., Cullen S. P., Martin S. J. (2008): Apoptosis: controlled demolition at the cellular level. Nat. Rev. Mol. Cell. Biol. 9, 231-241 http://dx.doi.org/10.1038/nrm2312

Yeung B. H., Huang D. C., Sinicrope F. A. (2006): PS-341 (bortezomib) induces lysosomal cathepsin B release and a caspase-2-dependent mitochondrial permeabilization and apoptosis in human pancreatic cancer cells. J. Biol. Chem. 281, 11923-11932 http://dx.doi.org/10.1074/jbc.M508533200

Yu C., Rahmani M., Dent P., Grant S. (2004): The hierarchical relationship between MAPK signaling and ROS generation in human leukemia cells undergoing apoptosis in response to the proteasome inhibitor Bortezomib. Exp. Cell Res. 295, 555-566 http://dx.doi.org/10.1016/j.yexcr.2004.02.001

Zapata J. M., Takahashi R., Salvesen G. S., Reed J. C. (1998): Granzyme release and caspase activation in activated human T-lymphocytes. J. Biol. Chem. 273, 6916-6920 http://dx.doi.org/10.1074/jbc.273.12.6916

Zhang L., Littlejohn J. E., Cui Y., Cao X., Peddaboina C., Smythe W. R. (2010): Characterization of bortezomib-adapted I-45 mesothelioma cells. Mol. Cancer 9, 110 http://dx.doi.org/10.1186/1476-4598-9-110

Received: July 22, 2014

Final version accepted: August 21, 2014

First published online: November 4, 2014 